\title{
Adaptation of Malt Barley (Hordeum Vulgare L.) Varieties in the highlands of North Gondar
}

\author{
Zeynu Tahir ${ }^{1}$, Asfaw Azanaw ${ }^{2 *}$ \\ Gondar Agricultural Research center, Gondar, P.O. Box 1337, ETHIOPIA \\ *Corresponding Contact: \\ Email: asfaw.azanaw@yahoo.com
}

Manuscript Received: 20 Dec 2018 - Revised: 24 Feb 2019 - Accepted: 10 March 2019

\begin{abstract}
Study was initiated with the objectives to identify high yielder malt barley varieties. The trial has been conducted during 2014 main season and laid out on randomized complete block design with three replications. Analysis of variance was computed using SAS, 2002. At Dabat, result showed that highly significant difference among the varieties $(\mathrm{p}<$ 0.05 ) for all agronomic traits. At Debark and Wegera the analysis of variance indicated that highly significant to a significant difference among varieties at $\mathrm{p}<0.05$ for days to heading, days to maturity, plant height, spike length, thousand seed weight and grain yield, and seed per spike. The combined analysis of variance showed that highly significant difference among varieties for days to heading, days to maturity, plant height, spike length, and grain yield. The location also contributed the significant effect for all yield components except biomass and grain yield. The interaction of location by genotype showed the highly significant difference on days to maturity and plant height. The average heading days ranged from $70-81$ and the average maturity days were ranged from 127-136. Among the tested varieties, IBON-174/03 and SABINI exhibited highest grain yield. The overall combined analysis indicated that IBON-174/03 and SABINI were high yielder and well adapted at the tested sites. Therefore those varieties are recommended for production in the testes sites, and similar agro-ecologies.
\end{abstract}

Keywords: Malt barley, variety, adaptation, yield, yield traits, variance

This article is is licensed under a Creative Commons Attribution-NonCommercial 4.0 International License.

Attribution-NonCommercial (CC BY-NC) license lets others remix, tweak, and build upon work non-commercially, and although the new works must also acknowledge \& be non-commercial.

\section{INTRODUCTION}

Barley (Hordeum vulgare L.) is one of the most important cereal crops in the world, ranking fourth in production area next to wheat, rice and maize (FAO, 2013). In Ethiopia, it was ranked fifth next to Tef, Wheat, Maize and Sorghum (CSA, 2016). Barley is adapt in diverse environments with the altitude range of 1500 and 3500 m.a.s.l, but predominantly grown from 2000 to 3000 m.a.s.l. Malt barley used as a variety of foods like biscuits, bread cakes and mostly used in beer production. It also has a desirable protein for animal diet (Emebiri et al., 2003).

To improve the productivity of the crop, research has been conducted over 40 years by different research institutions using exotic and landrace materials, and as a result of this effort several high yielding varieties have been released, and many of them are under production in their 
specific area of production. To successfully boost the production and productivity of this particular crop, improved agronomic management packages and inputs have been distributed to the farmers (Grando and Macpherson, 2005). Despite significant efforts made to generate and adapt improved production technologies, the regional average yield is still low compared to the world and national average yield. Therefore, there is a pressing need to introduce barley varieties to the high altitude and frost prone areas production system through evaluation of improved varieties that have been released by regional and national agricultural research centers aiming at national and regionally specific problems. Therefore, the objective of the research was to identify high yielder malt barley varieties in the high lands of North Gondar.

\section{Materials AND Methods}

\section{Description of the study areas}

Three experimental sites used in this study during the 2014 barley growing season. Debark site is located at 13.13166Nand 37.899121E. It is a trial site of Gondar Agricultural Research Center located at an altitude of 2885 m.a.s.l with annual average rainfall of $974 \mathrm{~mm}$ most of which falling between April and September having peaks in July and August. The temperature ranges from $8.6{ }^{\circ} \mathrm{C}$ to $19.8{ }^{\circ} \mathrm{C}$, and the soil type is classified as cambisol. Dabat site is located at $12.93178 \mathrm{Nand} 37.74412 \mathrm{E}$. It is a trial site of Gondar Agricultural Research Center located at an altitude of 2628 m.a.s.l with annual average rainfall of $758 \mathrm{~mm}$. Most of which falls between April and September having peaks in July and August. The average temperature is $16.6^{\circ} \mathrm{c}$, and the soil type is classified as cambisol. Wogera is located at 12.82254 Nand $37.70317 \mathrm{E}$. It is farmer's field located at an altitude of 2790 m.a.s.l. Soil type is classified as cambisol.

\section{Methodologies}

The experiment was conducted during 2014 main cropping season in the highlands of North Gondar zone at three districts, Wogera, Dabat, and Debark. Eight improved malt barley varieties were evaluated and compared for their yield and other agronomic performance. The trial was laid out in Randomized Complete Block Design with three replications. Each experimental plot had six rows of 2.5 meter length and 1.2 meter width. The gross and harvestable plot size was $2.5 \mathrm{~m}^{*} 1.2 \mathrm{~m}(3 \mathrm{~m} 2)$ and $0.8 \mathrm{~m}^{*} 2.5 \mathrm{~m}(2 \mathrm{~m} 2)$, respectively. The spacing between rows, plots and blocks were $0.2 \mathrm{~m}, 0.5 \mathrm{~m}$ and $1 \mathrm{~m}$, respectively.

Table1: Experimental Materials used in the experiment

\begin{tabular}{|l|l|l|l|l|l|}
\hline \multicolumn{1}{|c|}{ Varieties } & Year of Released & Released Center & Altitude (m.a.s.l) & Rainfall $(\mathrm{mm})$ & Protein (\%) \\
\hline BEKOJI-1 & 2010 & KARC & $2300-2800$ & $500-800$ & 11.8 \\
\hline TRAVLER & 2013 & HEINKEN/HARC & $2000-2800$ & $500-800$ & 10.1 \\
\hline EH-1847 & 2011 & HARC & $2300-2800$ & $500-800$ & 11.1 \\
\hline FRIEGEBS & 2010 & AARC & $2300-2800$ & $500-800$ & \\
\hline SABINI & 2011 & KARC & $2300-2800$ & $500-800$ & 10.7 \\
\hline BAHATI & 2011 & KARC & $2300-2800$ & $500-800$ & 10.4 \\
\hline IBON-174/03 & 2012 & HARC & $2300-2800$ & $500-800$ & 11.4 \\
\hline HOLKER & 1979 & HARC & $2500-3000$ & $500-800$ & 9.6 \\
\hline
\end{tabular}

Source: Gondar malt factory and released centers

Seed Rate of $85 \mathrm{~kg} / \mathrm{ha}$ was used in the experiment. The fertilizer was applied at the rate of $100 \mathrm{Kg} / \mathrm{ha}$ UREA and $100 \mathrm{~kg} / \mathrm{ha}$ DAP. Half of the total UREA and fully DAP at the time of planting while the remaining UREA at the time of tiller was used. Agronomic data were taken from the central four rows. Weeding and other agronomic practice were done as required. Analysis of variance was computed using the SAS statistical software (SAS, 2002). 


\section{RESULTS AND Discussions}

At Dabat trial site the analysis of variance showed that highly significant difference $(\mathrm{p} \leq 0.01)$ among treatment means for days to heading, days to maturity, plant height, spike length, biomass, and thousand seed weight. A significant difference $(p \leq 0.05)$ also observed among treatments for seeds per spike and grain yield. Days to heading ranged from 60 to 71days. IBON $174 / 03$ and SABINI started heading and matured earlier than the other tested varieties. This finding agrees with Yetsedaw et al., (2013) for IBON-174/03. Plant height ranged from $67 \mathrm{~cm}$ to $92.7 \mathrm{~cm}$.Among the treatments. Spike length ranged from 7.2 to $8.9 \mathrm{~cm}$. The longest spike length recorded from IBON-174/03 and the shortest was recorded from BEKOJI-1 (Table 2).

Table 2: Mean performance of yield and yield related traits of improved Malt Barley varieties during 2014 main season at Dabat district, North Gondar

\begin{tabular}{|l|l|l|l|l|l|l|l|l|}
\hline \multicolumn{9}{|c|}{ Mean values } \\
\hline Treatments & DHA & DMA & PLH & SPL & SPS & BMA & TSW & GYLD \\
\hline BEKOJI -1 & $71^{\mathrm{a}}$ & $121^{\mathrm{a}}$ & $88.6^{\mathrm{a}}$ & $7.2^{\mathrm{c}}$ & $25.4^{\mathrm{ab}}$ & $8.3^{\mathrm{d}}$ & $38.9^{\mathrm{d}}$ & $2760^{\mathrm{ab}}$ \\
\hline TRAVELER & $70^{\mathrm{ab}}$ & $121^{\mathrm{a}}$ & $67^{\mathrm{c}}$ & $8^{\mathrm{b}}$ & $23.8^{\mathrm{b}}$ & $10.8^{\mathrm{bc}}$ & $41.4^{\mathrm{cd}}$ & $4037^{\mathrm{a}}$ \\
\hline EH1847 & $68^{\mathrm{bc}}$ & $122^{\mathrm{a}}$ & $88.8^{\mathrm{a}}$ & $8.8^{\mathrm{a}}$ & $25.6^{\mathrm{ab}}$ & $10.3^{\mathrm{cd}}$ & $40.8^{\mathrm{d}}$ & $3932^{\mathrm{a}}$ \\
\hline FRIEGEBS & $64^{\mathrm{d}}$ & $122^{\mathrm{a}}$ & $92.7^{\mathrm{a}}$ & $7.9^{\mathrm{bc}}$ & $24.8^{\mathrm{b}}$ & $12.8^{\mathrm{ab}}$ & $46.9^{\mathrm{ab}}$ & $3473.3^{\mathrm{ab}}$ \\
\hline SABINI & $60^{\mathrm{e}}$ & $110^{\mathrm{b}}$ & $78.7^{\mathrm{b}}$ & $8.2^{\mathrm{ab}}$ & $26^{\mathrm{ab}}$ & $14.5^{\mathrm{a}}$ & $43.8^{\mathrm{c}}$ & $3648^{\mathrm{ab}}$ \\
\hline BAHATI & $67^{\mathrm{cd}}$ & $122^{\mathrm{a}}$ & $89.9^{\mathrm{a}}$ & $7.7^{\mathrm{bc}}$ & $25.7^{\mathrm{ab}}$ & $9.8^{\mathrm{cd}}$ & $47.4^{\mathrm{a}}$ & $3770^{\mathrm{ab}}$ \\
\hline IBON-174/03 & $60^{\mathrm{e}}$ & $109^{\mathrm{b}}$ & $86.7^{\mathrm{a}}$ & $8.9^{\mathrm{a}}$ & $28^{\mathrm{a}}$ & $13^{\mathrm{ab}}$ & $44.2^{\mathrm{bc}}$ & $4137^{\mathrm{a}}$ \\
\hline HOLKER & $70^{\mathrm{ab}}$ & $121^{\mathrm{a}}$ & $89.2^{\mathrm{a}}$ & $7.6^{\mathrm{bc}}$ & $26.2^{\mathrm{ab}}$ & $10.2^{\mathrm{cd}}$ & $39.7^{\mathrm{d}}$ & $3406.7^{\mathrm{ab}}$ \\
\hline Mean & 66 & 118 & 85 & 8 & 25.7 & 11.2 & 42.9 & 3645 \\
\hline CV $(\%)$ & 2.4 & 8.3 & 4.78 & 5.07 & 5.69 & 11.5 & 3.92 & 16.7 \\
\hline LSD & 3 & 2 & 7.1 & 0.71 & 2.56 & 2.3 & 2.94 & 1067.5 \\
\hline Treatment & $* *$ & $* *$ & $* *$ & $* *$ & $*$ & $* *$ & $* *$ & $*$ \\
\hline
\end{tabular}

*and ${ }^{* *}$ denote significant difference at $\mathrm{P}<0.05$ and $\mathrm{P}<0.01$, respectively. $\mathrm{NS}=\mathrm{Non}$ significant difference.DHA=Days to heading, DMA=Days to maturity, PLH=Plant height, SPL=Spike length, SPS=Seeds per spike, BMA=Biomass, TSW=Thousand seed weight and GYLD=Grain yield.

The numbers of grain per spike and grain weight are important features of cereals in determining the yield potential (Moral et al., 2002). Therefore, the highest seeds per spike were recorded from IBON-174/03 and SABINI. In addition to this those varieties exhibited the highest biomass among tested varieties. Yield is accumulative results of yield components, and it was ranged from 2760 to $4137 \mathrm{~kg} / \mathrm{ha}$. Thus, among tested genotypes, IBON-174/03 was high yielder whereas Bekoji-1was low yielder as compared to other varieties in the tested areas (Table 2). SABINI and IBON-174/03 had good agronomic performance and high yield potential among varieties. This finding agreed with Yetsedaw et al., (2013) for IBON-174/03. Therefore, those varieties recommended for Dabat and similar agro- ecologies.

At Debark, the analysis of variance indicated that highly significant difference $(\mathrm{p} \leq 0.01)$ among treatment means for plant height, thousand seed weight and grain yield. A significant difference $(\mathrm{p} \leq 0.05)$ also observed among treatments for agronomic traits for days to heading, days to maturity and spike length. Heading and maturity days at Debark were longer as compared to Dabat and Wogera trial site. Days to heading ranged from 90 to 100 days (Table 3). The shortest days to heading were recorded from Sabini (90 days) and IBON-174/03 (95 days), While the longest heading days were recorded from Bekoji-1 and Traveler (100days). Mean values of varieties for days to maturity ranged from 160 to 168 . Shortest maturity days were recorded from SABINI and IBON-174/03, while the longest maturity day was recorded from Friegebs. In plant height, the mean values of varieties ranged from $80 \mathrm{~cm}$ to $110 \mathrm{~cm}$. The shortest height was recorded from Traveler, while the longest height was recorded from Friegebs (Table 3). 
Table 3: The mean performance of yield and yield related traits of improved Malt barley varieties during 2014 main season at Debark district, North Gondar

\begin{tabular}{|l|l|l|l|l|l|l|l|l|}
\hline \multicolumn{9}{|c|}{ Mean values } \\
\hline Treatments & DHA & DMA & PLH & SPL & SPS & BMA & TSW & GYLD \\
\hline BEKOJI 1 & 100 & $164 \mathrm{ab}$ & $105 \mathrm{a}$ & $8.2 \mathrm{bc}$ & 31 & 8.1 & $48 \mathrm{~d}$ & $2907 \mathrm{c}$ \\
\hline TRAVELER & 100 & $161 \mathrm{ab}$ & $80 \mathrm{~d}$ & $9.2 \mathrm{ab}$ & 33 & 11 & $53 \mathrm{bc}$ & $4087 \mathrm{ab}$ \\
\hline EH-1847 & 98 & $164 \mathrm{ab}$ & $95 \mathrm{bc}$ & $9.5 \mathrm{a}$ & 35 & 10.5 & $48 \mathrm{~d}$ & $4497 \mathrm{a}$ \\
\hline FRIEGEBS & 98 & $168 \mathrm{a}$ & $110 \mathrm{a}$ & $9.3 \mathrm{ab}$ & 31.8 & 11.5 & $54 \mathrm{~b}$ & $3860 \mathrm{~b}$ \\
\hline SABINI & 90 & $160 \mathrm{~b}$ & $98 \mathrm{~b}$ & $9.3 \mathrm{ab}$ & 33 & 10.1 & $50 \mathrm{bcd}$ & $4552 \mathrm{a}$ \\
\hline BAHATI & 97 & $166 \mathrm{ab}$ & $106 \mathrm{a}$ & $8.7 \mathrm{abc}$ & 32 & 11 & $59 \mathrm{a}$ & $4027 \mathrm{ab}$ \\
\hline IBON 174/03 & 95 & $160 \mathrm{ab}$ & $90 \mathrm{c}$ & $9.7 \mathrm{a}$ & 33 & 11.2 & $54 \mathrm{~b}$ & $4200 \mathrm{ab}$ \\
\hline HOLKER & 96 & $166 \mathrm{ab}$ & $108 \mathrm{a}$ & $7.8 \mathrm{c}$ & 32 & 11 & $49 \mathrm{~cd}$ & $3758 \mathrm{~b}$ \\
\hline Mean & 97 & 163 & 99 & 8.9 & 32.6 & 10.58 & 51.9 & 3979 \\
\hline CV $(\%)$ & 3.1 & 2.7 & 3.9 & 7.2 & 6.39 & 19.8 & 5.5 & 8.2 \\
\hline LSD & 5 & 8 & 6.8 & 1.1 & 3.65 & 3.7 & 5 & 569 \\
\hline Treatment & $*$ & $*$ & $* *$ & $*$ & ns & ns & $* *$ & $* *$ \\
\hline
\end{tabular}

NB. *and ${ }^{* *}$ denote significant difference at $\mathrm{P}<0.05$ and $\mathrm{P}<0.01$, respectively. NS $=$ Non significant. $\mathrm{DHA}=$ Days to heading, DMA=Days to maturity, PLH=Plant height, SPL=Spike length, SPS=Seeds per spike, BMA=Biomass, TSW=Thousand seed weight and GYLD=Grain yield.

The mean value of genotypes in spike length ranged from $7.8 \mathrm{~cm}$ to $9.7 \mathrm{~cm}$. The longest spike length was recorded for IBON-174/03 followed by EH1847 and Sabini, respectively, while the shortest spike length was recorded for Holker (Table 3). The highest yield was recorded from SABINI followed by EH1847 and IBON-174/03 respectively, as reported by Yetsedaw et al., (2013) for EH-1847 and IBON174/03, while the lowest yield was recorded from BEKOJI (Table 3). Therefore, SABINI and IBON-174/03 recommended for Debark area base on their better adaptability and yield performance. At Wogera, the analysis of variance indicated that highly significant difference $(\mathrm{p} \leq 0.01)$ among treatment means for days to maturity, plant height and thousand seed weight (Table 3).

Table 4: The mean performance of yield and yield related traits of improved Malt barley varieties during 2014 main season at Wegera, district, North Gondar

\begin{tabular}{|l|l|l|l|l|l|l|l|l|}
\hline \multicolumn{9}{|c|}{ Mean values } \\
\hline Treatments & DHA & DMA & PLH & SPL & SPS & BMA & TSW & GYLD \\
\hline BEKOJI -1 & $71 \mathrm{ab}$ & $120 \mathrm{~b}$ & $98 \mathrm{ab}$ & $6.8 \mathrm{c}$ & 27.6 & 11.3 & $39.1 \mathrm{~cd}$ & $3372 \mathrm{abc}$ \\
\hline TRAVELER & $74 \mathrm{a}$ & $126 \mathrm{a}$ & $63 \mathrm{~d}$ & $7.9 \mathrm{ab}$ & 27.2 & 9.5 & $36.6 \mathrm{~d}$ & $2673 \mathrm{bc}$ \\
\hline EH-1847 & $64 \mathrm{bc}$ & $117 \mathrm{c}$ & $100 \mathrm{a}$ & $8.4 \mathrm{a}$ & 25.8 & 12.5 & $41.4 \mathrm{bc}$ & $4028 \mathrm{ab}$ \\
\hline FRIEGEBS & $65 \mathrm{bc}$ & $118 \mathrm{c}$ & $83 \mathrm{c}$ & $7.9 \mathrm{ab}$ & 26 & 8.7 & $46 \mathrm{a}$ & $1986 \mathrm{c}$ \\
\hline SABINI & $61 \mathrm{c}$ & $112 \mathrm{c}$ & $85 \mathrm{bc}$ & $7.9 \mathrm{ab}$ & 27 & 13.3 & $44 \mathrm{ab}$ & $4473 \mathrm{a}$ \\
\hline BAHATI & $72 \mathrm{ab}$ & $117 \mathrm{c}$ & $87 \mathrm{abc}$ & $6.9 \mathrm{c}$ & 29.6 & 11.4 & $43.7 \mathrm{ab}$ & $3623 \mathrm{abc}$ \\
\hline IBON 174/03 & $61 \mathrm{c}$ & $112 \mathrm{c}$ & $93 \mathrm{abc}$ & $7.9 \mathrm{ab}$ & 28.4 & 11.7 & $44.7 \mathrm{ab}$ & $4438 \mathrm{a}$ \\
\hline HOLKER & $71 \mathrm{ab}$ & $120 \mathrm{~b}$ & $89 \mathrm{abc}$ & $6.7 \mathrm{c}$ & 28.9 & 11.9 & $38.5 \mathrm{~cd}$ & $3370 \mathrm{abc}$ \\
\hline Mean & 67.5 & 117.9 & 87.3 & 7.5 & 27.6 & 11.3 & 41.8 & 3496.8 \\
\hline CV $(\%)$ & 7.07 & 5.5 & 9.4 & 7.4 & 8.7 & 18.3 & 5.3 & 24.6 \\
\hline LSD & 8 & 11 & 14.4 & 1 & 4.2 & 3.6 & 3.9 & 1721.5 \\
\hline Treatment & $*$ & $* *$ & $* *$ & $*$ & Ns & Ns & $* *$ & $*$ \\
\hline
\end{tabular}

*and ** denote significant difference at $\mathrm{P}<0.05$ and $\mathrm{P}<0.01$, respectively. $\mathrm{NS}=$ Non significant.DHA=Days to heading, DMA=Days to maturity, PLH=Plant height, SPL=Spike length, SPS=Seeds per spike, BMA=Biomass, TSW=Thousand seed weight and GYLD=Grain yield. 
A significant difference also showed at $(\mathrm{p}<0.05)$ for days to heading, spike length, and grain yield. Days to heading ranged from 61-74 days. The shortest days to heading recorded for SABINI and IBON-174/03 (61 days) while the longest days to heading recorded for Traveler (74 days). Mean values of days to maturity ranged from 111-126days (Table 4). The longest days to maturity recorded for Traveler (126 days) followed by Holker (120 days) and BEKOJI (120 days) (Table 4).

IBON-174/03 and Sabini significantly start heading earlier and mature early than the other varieties. Mean values of plant height ranged from $63-100 \mathrm{~cm}$. The tallest varieties were EH- 1847 followed by Bekji-1 and IBON-174/03, while shortest height was recorded from Traveler (Table 4). Mean values of varieties in spike length ranged from $6.7-8.4 \mathrm{~cm}$. The longest spike length was recorded for EH-1847 $(8.4 \mathrm{~cm})$, while the shortest spike length was recorded for Holker $(6.7 \mathrm{~cm})$. Grain weight is important features of cereals in determining the yield potential (Moral et al., 2002). Thus, thousand seed weight ranged from 36.6-46gm. At Wogera highest thousand seed weight was recorded from FRIEGEBS (46gm), while the lowest was recorded from Traveler (36.6gm). Yield is a cumulative result of yield components, thus among tested varieties the highest grain yield recorded from SABINI and IBON-174/03, while lowest grain yield recorded from Friegebs (Table 4). Therefore IBON174/03 and SABINI are recommended for production at wogera area.

Table 5: The mean performance of combined analysis of Malt barley varieties tested at Dabat, Debark and Wegera station (2014 cropping season).

\begin{tabular}{|c|c|c|c|c|c|c|c|c|}
\hline \multicolumn{9}{|c|}{ Mean values } \\
\hline Varieties & DHA & DMA & PLH & SPL & SPS & BMA & TSW & GYLD \\
\hline BEKOJI 1 & $81 a$ & $135 a$ & $97.4 \mathrm{a}$ & $7.4 \mathrm{e}$ & 28.1 & $9.2 \mathrm{c}$ & $41.8 \mathrm{~d}$ & $3013 c$ \\
\hline TRAVELER & $81 a$ & $136 a$ & $70.1 \mathrm{~d}$ & $8.4 \mathrm{bc}$ & 28.1 & $10.5 b c$ & $43.7 \mathrm{~d}$ & $3599 a-c$ \\
\hline EH1847 & $77 \mathrm{bc}$ & $134 a$ & $95 \mathrm{ab}$ & $9 a$ & 29 & $11.3 \mathrm{ab}$ & $43.3 \mathrm{~d}$ & 4152ab \\
\hline FRIEGEBS & $76 c$ & $136 a$ & $95.2 \mathrm{ab}$ & $8.2 \mathrm{~cd}$ & 27.6 & $11.1 \mathrm{ab}$ & $49.2 \mathrm{ab}$ & $3107 \mathrm{c}$ \\
\hline SABINI & $70 \mathrm{~d}$ & $127 \mathrm{~b}$ & $87.5 c$ & $8.4 \mathrm{bc}$ & 28.8 & $12.7 \mathrm{a}$ & $46 c$ & $4228 a$ \\
\hline BAHATI & $79 \mathrm{ab}$ & $135 a$ & $94.5 \mathrm{ab}$ & 7.7de & 29.2 & $10.7 \mathrm{bc}$ & $50.3 a$ & $3807 \mathrm{ab}$ \\
\hline IBON 174/03 & $72 \mathrm{~d}$ & $127 \mathrm{~b}$ & $90 \mathrm{bc}$ & $9 \mathrm{a}$ & 29.7 & $12.1 \mathrm{ab}$ & $49 \mathrm{ab}$ & $4239 a$ \\
\hline HOLKER & $79 \mathrm{ab}$ & $135 a$ & $95.4 \mathrm{a}$ & $7.4 \mathrm{e}$ & 28.9 & $11.1 \mathrm{ab}$ & $42.2 \mathrm{~d}$ & $3512 \mathrm{bc}$ \\
\hline Mean & 77 & 133 & 91 & 8.2 & 28.7 & 11.1 & 45.5 & 3707 \\
\hline $\mathrm{CV}(\%)$ & 4.4 & 2 & 6.5 & 6.9 & 7.2 & 16.7 & 5.1 & 18.7 \\
\hline LSD & 3 & 2.5 & 5.5 & 0.54 & 2 & 2 & 2.2 & 660 \\
\hline Treatment & ** & $* *$ & $* *$ & $* *$ & ns & * & $* *$ & $* *$ \\
\hline Location & $* *$ & $* *$ & $* *$ & $* *$ & ** & ns & $* *$ & ns \\
\hline Loc. ${ }^{*}$ Trt. & ns & ** & ** & ns & ns & $*$ & $*$ & ns \\
\hline
\end{tabular}

\section{Combined Analysis}

The combined analysis of variance showed that highly significant difference among varieties for, days to heading, days to maturity, plant height, spike length, and grain yield. Biomass also exhibited significant difference, but seeds per spike showed no significant difference among varieties. The location also contributed to the significant effect for all yield components, but the final biomass and grain yield was not affected by location (non-significant). The interaction of both location and genotype showed a highly significant effect on days to maturity and plant height. The interaction effect also contributed to biomass yield. The rest of the yield and yield components were not affected by the interaction of location by genotype. Therefore, all varieties had similar yield performance across location. The average heading days ranged from 70-81 Days and minimum and maximum days was recorded on varieties SABINI (70days), TRAVELER (81days) and BEKOJI-1 (81 Days), respectively. The average maturity days ranged from 127-136 
days. The minimum and maximum days was recorded on SABINI and IBON 174/03(127 Days) and TRAVELER (136 Days). IBON-174 and SABINI are early matured varieties among tested varieties. Average plant height ranged from $70-97 \mathrm{~cm}$. Among the varieties, TRAVELER has the shortest height $(70 \mathrm{~cm})$, and BEKOJI has the longest height $(97 \mathrm{~cm})$ among tested varieties. Average biomass yield ranged from 9.2-12.7t/ha. Lower and higher average biomass was recorded on variety BEKOJI-1(9.2t/ha) and SABINI (12.7t/ha). Among the tested varieties, IBON-174/03 and SABINI exhibited maximum biological yield. Finally, the tested varieties exhibited average grain yield from 3013-4239 kg/ha. The lowest and highest grain yield was recorded on variety BEKOJI$1(3013 \mathrm{~kg} / \mathrm{ha})$ and IBON- 174/03(4239kg/ha), respectively. The overall combined analysis indicated IBON-174 and SABINI varieties are high yielder and well adapted at the tested sites.

\section{CONCLUSION}

The analysis of each location and aver all combined analysis of variance of three environments indicated that highly significant difference at $p \leq 0.05$. The interaction of environment by genotype contributed highly significant and significant effect on days to maturity, plant height and biomass yield, respectively. The rest of the yield and yield components were not affected by the interaction of environment by genotype. Therefore, all varieties had similar yield performance across location. Among tested varieties in three locations Ibon-174/03 and Sabini were early maturing type and well adapted and high yielder. Therefore, those varieties are recommended in the highland areas of North Gondar Zone and similar agro- ecologies.

\section{ACKNOWLEDGMENT}

Our gratefulness and thanks are going to Gondar Agricultural Research Center (GARC) for granting us financial support and provision of the necessary materials. Our sincere thanks go also to crop science directorate staff of GARC.

\section{REFERENCES}

CSA (2016). Central Statistics Authority Report on Area and Production of Crops. Statistical Bulletin of Agricultural Sample Survey, No. 579, Addis Ababa, Ethiopia

Emebiria L, Moodya D, Panozzoa JF, Readb J (2003). Mapping of QTL for malting quality attributes in barley based on a cross of parents with low grain protein concentration. Department of Primary Industries, Research and Development Division, Natimuk Road, Private Bag 260, Horsham, Vic. 3401, Australia.

FAO (2013). Food and Agriculture Organization of theUnited Nations. Estimates of world production and harvested area. Data from FAOSTAT.fao.org.

Grando S and Macpherson HG (eds.) (2005). Food Barley: Importance, Uses and Local Knowledge. Proceedings of the International Workshop on Food Barley Improvement, 14-17 January 2002, Hammamet, Tunisia. ICARDA, Aleppo, Syria, x+156 pp. En.

Lakew B, Gebre H and Alemayehu F. 1996. Barley production and research. Pp. 1-8. In: H. Gebre and J. van Leur, (eds). Proceedings, First Barley Research Review Workshop, Addis Ababa, Ethiopia, 16-19 October 1993, IAR/ICARDA

Moral LFG, Miralles DJ, Slafer GA (2002). Initiation and appearance of vegetative and reproductive structures throughout barley development. In: Barley Science: Recent Advances from Molecular Biology to Agronomy of Yield and Quality. Slafer G. A. et al. (eds.) Food Products Press, New York, London, Oxford, 243-268.

SAS (2002). SAS/STAT user's guide, Version 9.0. SAS Institute Inc., Cary, NC.

Yetsedaw A, Tadesse D and Wondimu B (2013). Participatory evaluation of malt barley (Hordeum vulgare L.) genotypes for yield and other agronomic traits at North-West Ethiopia. Vol. 2(8), pp. 218 - 222

$$
--0--
$$

